Vol. 5 (1996): 193-202.

\title{
Release of soil phosphorus during runoff as affected by ionic strength and temperature
}

Markku Yli-Halla' and Helinä Hartikainen

Department of Applied Chemistry and Microbiology, P.O. Box 27, FIN-00014 University of Helsinki, Finland

Dissolved reactive phosphorus (DRP) from two cultivated clay soil samples (Vertic Cambisols) was extracted under conditions simulating the variation in the properties of surface runoff water in the field. DRP was extracted at three temperatures $\left(5,15\right.$ and $\left.25^{\circ} \mathrm{C}\right)$, and at different ionic strengths by using deionized water and $\mathrm{CaCl}_{2}$ solutions $(0.00005-0.005 \mathrm{M})$ as extractants. The solution-to-soil ratio varied from 50 to $20001 \mathrm{~kg}^{-1}$. Sorption to and desorption from the soils were studied at different temperatures and ionic strengths by determining quantity-intensity $(\mathrm{Q} / \mathrm{I})$ plots at the solution-to-soil ratio of $501 \mathrm{~kg}^{-1}$, and the results were fitted to a modified Langmuir equation:

$$
\mathrm{Q}=\mathrm{Q}_{\max } \mathrm{I} /(1 / \mathrm{K}+\mathrm{I})-\mathrm{Q}_{0}
$$

where $\mathrm{Q}$ is $\mathrm{P}$ sorbed or desorbed, $\mathrm{Q}_{\max }=$ maximum $\mathrm{P}$ sorption, $\mathrm{I}=\mathrm{P}$ concentration in the equilibrium solution, $\mathrm{K}=$ sorption/desorption equilibrium constant, and $\mathrm{Q}_{0}=$ instantly labile $\mathrm{P}$. The desorption of DRP was depressed by increases in the $\mathrm{CaCl}_{2}$ concentration of the extractant and promoted by widening of the solution-to-soil ratio. At the solution-to-soil ratio of $50 \mathrm{l} \mathrm{kg}^{-1}$, the increase in the temperature from 5 to $25^{\circ} \mathrm{C}$ raised the DRP release to water from 12.6 to $20.7 \mathrm{mg} \mathrm{kg}^{-1}$ in the Aurajoki soil and from 1.8 to $3.4 \mathrm{mg} \mathrm{kg}^{-1}$ in the Jokioinen soil. In the Aurajoki soil, the constant $\mathrm{Q}_{0}$ of the Langmuir equation responded to the changes of ionic strength and temperature in the same way as did DRP extracted at wide solution-to-soil ratios. However, the P release capacity of both soils was underestimated by the constant $\mathrm{Q}_{0}$.

Key words: water extraction, $\mathrm{CaCl}_{2}$ extraction, solution-to-soil ratio, modified Langmuir equation, phosphorus loading of surface waters

' Current address: Agricultural Research Centre of Finland, Institute of Soils and Environment, FIN-31600 Jokioinen, Finland

\section{Introduction}

Surface runoff water transports phosphorus $(\mathrm{P})$ from soil to watercourses in the dissolved form and in the particulate material. In areas of frozen soil and snow coverage in winter, the volume of surface runoff water peaks in spring during the thaw, another peak often occurring in autumn. Erosion and removal of dissolved $\mathrm{P}$ are 


\section{Yli-Halla, M. \& Hartikainen, H.: Phosphorus desorption to runoff water}

also most intensive during these periods (Turtola and Jaakkola 1995). The equilibrium P concentration (EPC) in the solution where the particulate material collected from river water neither released or adsorbed $\mathrm{P}$ was shown to be lower than $0.010 \mathrm{mg} \mathrm{P} \mathrm{l}^{-1}$ which is decisively below the EPC obtained for cultivated soils (e.g. Hartikainen 1982b, Yli-Halla 1991, Yli-Halla et al. 1995). Pietiläinen and Ekholm (1992) showed that $90 \%$ of particulate material in a small agriculturally loaded river in southern Finland was recently eroded from the surface soil of the fields of the drainage basin. Comparison of the results above thus reveals that $\mathrm{P}$ must be effectively desorbed during the erosion process.

Dissolved $\mathrm{P}$ in the runoff water originates partly from the bulk of the soil remaining in the field and partly from suspended particles. Soil $\mathrm{P}$ status, to some extent, explains the average dissolved reactive $\mathrm{P}$ (DRP) concentration in runoff water but not the temporal variation of DRP (YliHalla et al. 1995). The temperature during the runoff peaks in autumn and particularly in spring is much lower (between 0 and $5^{\circ} \mathrm{C}$ ) as compared

Table 1. Properties of the experimental soils.

\begin{tabular}{|c|c|c|}
\hline Characteristic & Aurajoki soil & Jokioinen soil \\
\hline Clay, \% & 60.1 & 58.5 \\
\hline Organic C, \% & 2.8 & 1.4 \\
\hline Soil $\mathrm{pH}\left(\mathrm{CaCl}_{2}\right)$ & 5.72 & 5.14 \\
\hline $\mathrm{Al}_{\mathrm{ox}}, \mathrm{g} \mathrm{kg}^{-1^{*}}$ & 1.05 & 2.22 \\
\hline $\mathrm{Fe}_{\mathrm{og}}, \mathrm{g} \mathrm{kg}^{-1^{*}}$ & 7.23 & 7.03 \\
\hline $\mathrm{P}_{\mathrm{w}}, \mathrm{mg} \mathrm{kg}^{-1 *}$ & 27.5 & 3.6 \\
\hline $\mathrm{P}_{\mathrm{Ac}} \cdots, \mathrm{mg} \mathrm{dm}^{-3}$ of soil & 27.1 & 5.1 \\
\hline $\mathrm{NH}_{4} \mathrm{Cl}-\mathrm{P}, \mathrm{mg} \mathrm{kg}^{-1 \cdots \cdots}$ & 5.2 & 0.2 \\
\hline $\mathrm{NH}_{4} \mathrm{~F}-\mathrm{P}, \mathrm{mg} \mathrm{kg}^{-1 \cdots \cdots}$ & 132 & 80 \\
\hline $\mathrm{NaOH}-\mathrm{P}, \mathrm{mg} \mathrm{kg}^{-1 \cdots *}$ & 527 & 423 \\
\hline $\mathrm{H}_{2} \mathrm{SO}_{4}-\mathrm{P}, \mathrm{mg} \mathrm{kg}^{-1 \cdots}$ & 475 & 172 \\
\hline Sum of fractions, $\mathrm{mg} \mathrm{kg}^{-1 \cdots}$ & 1139 & 675 \\
\hline
\end{tabular}

- Extracted with $0.05 \mathrm{M}$ ammonium oxalate, pH 3.3 (Niskanen 1989)

". P extracted with water, solution-to-soil ratio $501 \mathrm{~kg}^{-1}$

*. Pextracted with an ammonium acetate solution, $\mathrm{pH} 4.65$ (Vuorinen and Mäkitie 1955)

... Chang and Jackson fractions of inorganic P (Hartikainen 1979) to temperatures prevailing during the occasional summer rainstorms (commonly around $15^{\circ} \mathrm{C}$ ) and to room temperatures at which laboratory experiments are usually done. There is also a marked seasonal variation in other external conditions (ionic strength and volume of runoff water) prevailing during runoff events.

In this study, a set of desorption tests was carried out to quantify the impact of environmental factors on the $\mathrm{P}$ loading risk due to the surface runoff from cultivated soils. The temperature as well as ionic strength and solutionto-soil ratio were varied to simulate their changes during the runoff and erosion process and material transport in watercourses. The impact of temperature and external ionic strength on the dynamic equilibrium between solution and solid material was investigated by means of the quantity-intensity $(\mathrm{Q} / \mathrm{I})$ plots. The instantly labile $\mathrm{P}$ derived from these graphs was used as one estimate for the P loading risk due to runoff water. The suitability of the $\mathrm{Q} / \mathrm{I}$ plots to predict $\mathrm{P}$ release from soil was also evaluated.

\section{Material and methods}

\section{Soil samples}

The soil samples of Aurajoki and Jokioinen (Table 1) were taken from experimental fields set up for studies on surface runoff. They represent fields with high and low level of $\mathrm{P}$ concentration in runoff, respectively (Yli-Halla et al. 1995). Both soils, located in southwestern Finland, are classified as Vertic Cambisols (FAO 1988). The soil samples were taken from the $0-10 \mathrm{~cm}$ layer. After air-drying and homogenization, the samples were rewetted to a moisture content of $20 \%$ and stored at $5^{\circ} \mathrm{C}$ for several weeks before the analyses. Air-dry samples were analyzed for $\mathrm{pH}$ in a $0.01 \mathrm{M} \mathrm{CaCl}_{2}$ suspension and for water-extractable $\mathrm{P}(1 \mathrm{~g}$ of soil, $50 \mathrm{ml}$ of deionized water, 17 hours of equilibration; Hartikainen 1982a). 
Vol. 5 (1996): 193-202.

\section{Desorption tests}

To study the effect of ionic strength on P desorption from soil, deionized water, $0.0005 \mathrm{M}$ and $0.005 \mathrm{M} \mathrm{CaCl}_{2}$ were used as extracting solutions at room temperature $\left(25^{\circ} \mathrm{C}\right)$. The selection of $\mathrm{CaCl}_{2}$ is based on the dominance of $\mathrm{Ca}$ among the exchangeable cations of the experimental soils (results not presented). For the extractions, moist soil samples (four replicates) were weighed to give dry soil concentrations of 0.5 , $1,2,5$ and $20 \mathrm{~g} \mathrm{l}^{-1}$ of the extractant (solution-tosoil ratio $2000-501 \mathrm{~kg}^{-1}$ ). The soil suspensions were shaken for $17 \mathrm{~h}$ in an orbital shaker at a speed of 250 rotations $\mathrm{min}^{-1}$. According to preliminary experiments, this reaction time was well sufficient to reach a semi equilibrium. The supernatant solutions were filtered through a membrane filter $(0.2 \mu \mathrm{m}$, Nuclepore polycarbonate) and analyzed for dissolved reactive P (DRP) by a molybdenum blue method using ascorbic acid as the reducing agent. The effect of temperature on $\mathrm{P}$ desorption was studied by extracting soil with deionized water at 5,15 and $25^{\circ} \mathrm{C}$. At each temperature, the extractions were carried out at solution-to-soil ratios from 50 to $20001 \mathrm{~kg}^{-1}$. The soil samples and the solutions to be added were adapted to the respective temperatures before the extraction. Phosphorus was determined as mentioned above.

\section{Q/I plots}

The Q/I plots were applied to express the sorption or desorption as a function of the P concentration in the equilibrium solution. They were determined in three replicates by adding $50 \mathrm{ml}$ of $\mathrm{KH}_{2} \mathrm{PO}_{4}$ solution $\left(0-4 \mathrm{mg} \mathrm{P} \mathrm{l}^{-1}\right.$ for Aurajoki samples, $0-5 \mathrm{mg} \mathrm{P}^{-1}$ for Jokioinen samples) to moist samples corresponding to $1 \mathrm{~g}$ of dry soil (solution-to-soil ratio $501 \mathrm{~kg}^{-1}$, or concentration of suspended solids $20 \mathrm{~g} \mathrm{l}^{-1}$ ). The extracts were obtained as described above and analyzed for DRP. The Q/I plots were determined at three temperatures: 5,15 and $25^{\circ} \mathrm{C}$. At $25^{\circ} \mathrm{C}$, the plots were also determined using $0.005 \mathrm{M}, 0.0005 \mathrm{M}$ and $0.00005 \mathrm{M} \mathrm{CaCl}_{2}$ as the supporting electrolytes. The ionic strengths of soil extracts were estimated from the electrical conductivity according to Griffin and Jurinak (1973).

Sorption to or desorption from soil (Y) in $\mathrm{mg}$ $\mathrm{P} \mathrm{kg}^{-1}$ was calculated from the changes in $\mathrm{P}$ concentration of the contacting solution and fitted to a modified Langmuir equation (Hartikainen and Simojoki 1994):

$$
\mathrm{Q}=\mathrm{Q}_{\max } \mathrm{I} /(1 / \mathrm{K}+\mathrm{I})-\mathrm{Q}_{0}
$$

where $\mathrm{Q}$ is $\mathrm{P}$ desorbed or sorbed, $\mathrm{Q}_{\max }=$ maximum $\mathrm{P}$ sorption, $\mathrm{I}=\mathrm{P}$ concentration in the final equilibrium solution, $\mathrm{K}=$ sorption/desorption equilibrium constant, and $\mathrm{Q}_{0}=$ instantly labile P. Mathematically, the isotherm will intersect the $y$-axis when $I=0$. According to Beckett and White (1964), the intercept (term $Q_{0}$ in the equation) represents what was termed instantly labile $\mathrm{P}$ that would have to be removed from the soil to reduce I to zero at a given solution-tosoil ratio. The intersecting point of the graph on the $x$-axis $(Y=0)$, the equilibrium phosphate concentration (EPC), represents the zero point of $\mathrm{P}$ exchange at which no net desorption from or sorption to soil occurs. The slope of the sorption-desorption curve at the EPC was referred to by Holford and Mattingly (1976) as the equilibrium buffer capacity (EBC).

\section{Results}

\section{Desorption tests}

At every solution-to-soil ratio, the two $\mathrm{CaCl}_{2}$ solutions extracted much less $\mathrm{P}$ than did water (Fig. 1). At the solution-to-soil ratio of $501 \mathrm{~kg}^{-1}$ the $\mathrm{P}$ concentration in the extract was lowered from 0.42 to $0.14 \mathrm{mg} \mathrm{l}^{-1}$ in the Aurajoki soil and in the Jokioinen soil from 0.068 to $0.015 \mathrm{mg} \mathrm{l}^{-1}$ when the ionic strength of the soil extract, shown in Table 2, increased from $0.3-0.5 \mathrm{mmol} \mathrm{l}^{-1}$ (water extract) to $16 \mathrm{mmol} \mathrm{l}^{-1}\left(0.005 \mathrm{M} \mathrm{CaCl}_{2}\right.$ extract). Relatively, the decrease in $\mathrm{P}$ desorption 


\section{AGRICULTURAL AND FOOD SCIENCE IN FINLAND}

Yli-Halla, M. \& Hartikainen, H.: Phosphorus desorption to runoff water
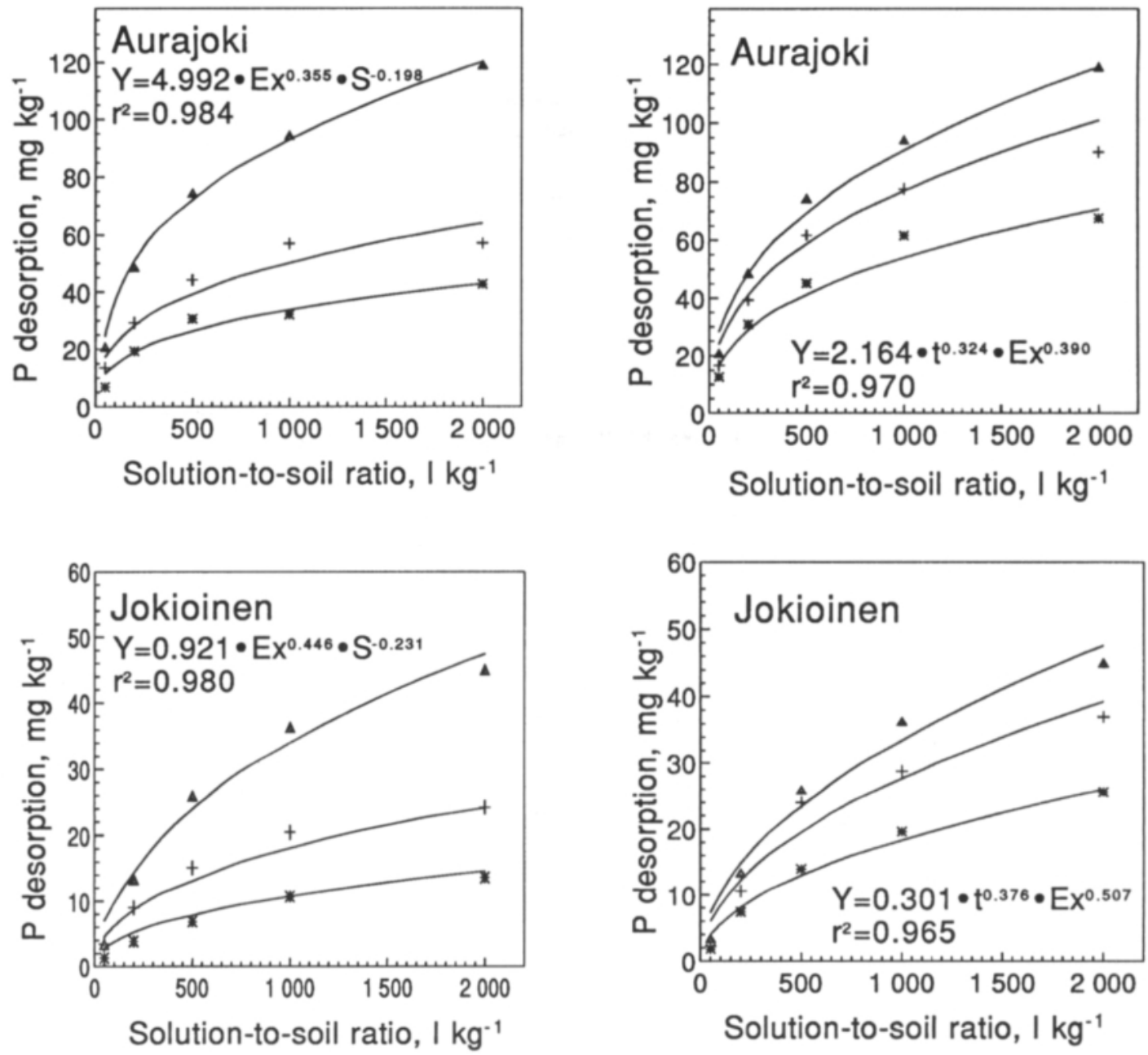

\begin{tabular}{|l|}
\hline Extractant \\
ه Water \\
$+0.0005 \mathrm{M}$ \\
$* 0.005 \mathrm{M}$
\end{tabular}

Fig. 1. Phosphorus extracted from the Aurajoki and Jokioinen soil with deionized water, $0.0005 \mathrm{M}$ and $0.005 \mathrm{M} \mathrm{CaCl}_{2}$ solutions at different solution-to-soil ratios (Ex). In the calculation of the equations, the ionic strengths $\left(\mathrm{S}, \mathrm{mmol} \mathrm{l}^{-1}\right)$ estimated from the measured electrical conductivities of the soil extracts were used.

was equal in both soils. If desorption to water is denoted as 100 , the relative desorption to 0.0005 $\mathrm{M}$ and $0.005 \mathrm{M} \mathrm{CaCl}_{2}$ was 66 and 33 in the $\mathrm{Au}-$

Temperature
$\Delta 25^{\circ} \mathrm{C}$
$+15^{\circ} \mathrm{C}$
$* 5^{\circ} \mathrm{C}$

Fig. 2. Phosphorus extracted from the Aurajoki and Jokioinen soil at three temperatures $(\mathrm{t})$ with deionized water at different solution-to-soil ratios (Ex).

rajoki soil, and 68 and 30 in the Jokioinen soil, respectively. 
Vol. 5 (1996): 193-202.

Table 2. Ionic strengths of water extracts and the $\mathrm{CaCl}_{2}$ extracts at the solution-to-soil ratio $501 \mathrm{~kg}^{-1}$.

\begin{tabular}{lcc}
\hline Extractant & \multicolumn{2}{c}{ Ionic strength, $\mathrm{mmol} \mathrm{l}^{-1}$} \\
\cline { 2 - 3 } & Aurajoki & Jokioinen \\
\hline Water & 0.51 & 0.29 \\
$0.0005 \mathrm{M} \mathrm{CaCl}_{2}$ & 2.13 & 1.94 \\
$0.005 \mathrm{M} \mathrm{CaCl}_{2}$ & 15.92 & 15.70 \\
\hline
\end{tabular}

At the solution-to-soil ratio of $501 \mathrm{~kg}^{-1}$, elevation of temperature from 5 to $25^{\circ} \mathrm{C}$ enhanced $\mathrm{P}$ desorption markedly. The DRP concentration in the water extracts increased in the Aurajoki soil from 0.25 to $0.42 \mathrm{mg} \mathrm{l}^{-1}$ (by $68 \%$ ) and in the Jokioinen soil from 0.037 to $0.068 \mathrm{mg} \mathrm{l}^{-1}$ (by $84 \%)$. The quantities of $\mathrm{P}$ desorbed $\left(\mathrm{mg} \mathrm{kg}^{-1}\right)$ with water at the three temperatures and the honest significant differences at $\mathrm{P}=0.05\left(\mathrm{HSD}_{0.05}\right)$ were:

$\begin{array}{llll} & \text { Aurajoki } & & \text { Jokioinen } \\ 5^{\circ} \mathrm{C} & 12.6 & & 1.8 \\ 15^{\circ} \mathrm{C} & 16.6 & 2.2 \\ 25^{\circ} \mathrm{C} & 20.7 & 3.4 \\ \mathrm{HSD}_{0.05} & 3.5 & 0.3\end{array}$

Increasing the volume of water around the soil particles lowered the ionic strength and the DRP concentration in the extract (Table 3). Owing to the strong $\mathrm{P}$ buffer power of the soil, however, the decrease of DRP concentration was even less linear than that of the ionic strength.
Consequently, the desorption of $\mathrm{P}$, expressed as $\mathrm{mg} \mathrm{kg}^{-1}$, was strongly promoted (Fig. 2). Desorption increased from 20.7 to $119 \mathrm{mg} \mathrm{kg}^{-1}$ in the Aurajoki soil and from 3.4 to $45.0 \mathrm{mg} \mathrm{kg}^{-1}$ in the Jokioinen soil at $25^{\circ} \mathrm{C}$ when the solution-tosoil ratio increased from 50 to $20001 \mathrm{~kg}^{-1}$.

\section{Q/I plots}

The Q/I plots crossed from net desorption to net sorption, and the results conformed accurately to the modified Langmuir equation $\left(r^{2}>0.99\right)$ (Fig. 3 and Fig. 4). However, for Jokioinen soil, the graphs intersected the $\mathrm{x}$-axis close to the origin and the desorption remained very small at the solution-to-soil ratio of $50 \mathrm{l} \mathrm{kg}^{-1}$ at which the Q/I plots were determined. In both soils, sorption increased and desorption decreased when $\mathrm{CaCl}_{2}$ solutions were used as extractants (Fig. 3). The EPC values obtained in $0.005 \mathrm{M} \mathrm{CaCl}_{2}$ were less than one fifth of that measured with out a supporting electrolyte (i.e., in water), and the EBC increased substantially upon increase of the ionic strength (Table 4). Despite the similar level of ionic strengths $\left(0.3 \mathrm{mmol}^{-1}\right.$ in water extracts, $0.5 \mathrm{mmol} \mathrm{l}^{-1}$ in $0.00005 \mathrm{M} \mathrm{CaCl}_{2}$ extracts) in the Jokioinen soil, the Q/I plot in the $\mathrm{CaCl}_{2}$ solution was markedly steeper.

The Q/I plots determined at 5,15 and $25^{\circ} \mathrm{C}$ (Fig. 4) showed that both desorption and sorption of $\mathrm{P}$ were promoted by gradual elevation of temperature. Both EBC and EPC increased upon

Table 3. DRP concentration and ionic strength of the water extracts obtained at different solution-to-soil ratios at $25^{\circ} \mathrm{C} .^{1}$

\begin{tabular}{|c|c|c|c|c|}
\hline \multirow{2}{*}{$\begin{array}{l}\text { Solution-to-soil } \\
\text { ratio, } 1 \mathrm{~kg}^{-1}\end{array}$} & \multicolumn{2}{|c|}{ DRP, $\mathrm{mg} \mathrm{l}^{-1}$} & \multicolumn{2}{|c|}{ Ionic strength, $\mathrm{mmol} \mathrm{l}^{-1}$} \\
\hline & Aurajoki & Jokioinen & Aurajoki & Jokioinen \\
\hline 50 & $0.415^{e}$ & $0.068^{d}$ & $0.51^{\mathrm{c}}$ & $0.29^{c}$ \\
\hline 200 & $0.243^{\mathrm{d}}$ & $0.065^{\mathrm{d}}$ & $0.23^{\mathrm{b}}$ & $0.19^{b}$ \\
\hline 500 & $0.149^{\circ}$ & $0.052^{\mathrm{c}}$ & $0.15^{\mathrm{ab}}$ & $0.12^{\mathrm{a}}$ \\
\hline 1000 & $0.094^{b}$ & $0.036^{\mathrm{b}}$ & $0.09^{\mathrm{ab}}$ & $0.10^{\mathrm{a}}$ \\
\hline 2000 & $0.060^{\mathrm{a}}$ & $0.023^{\mathrm{a}}$ & $0.09^{\mathrm{a}}$ & $0.09^{\mathrm{a}}$ \\
\hline $\mathrm{HSD}_{0.05}$ & 0.030 & 0.011 & 0.12 & 0.05 \\
\hline
\end{tabular}

' Each column was tested separately. Means marked with the same superscript do not differ at $\mathrm{P}=0.05$. 


\section{AGRICULTURAL AND FOOD SCIENCE IN FINLAND}

Yli-Halla, M. \& Hartikainen, H.: Phosphorus desorption to runoff water
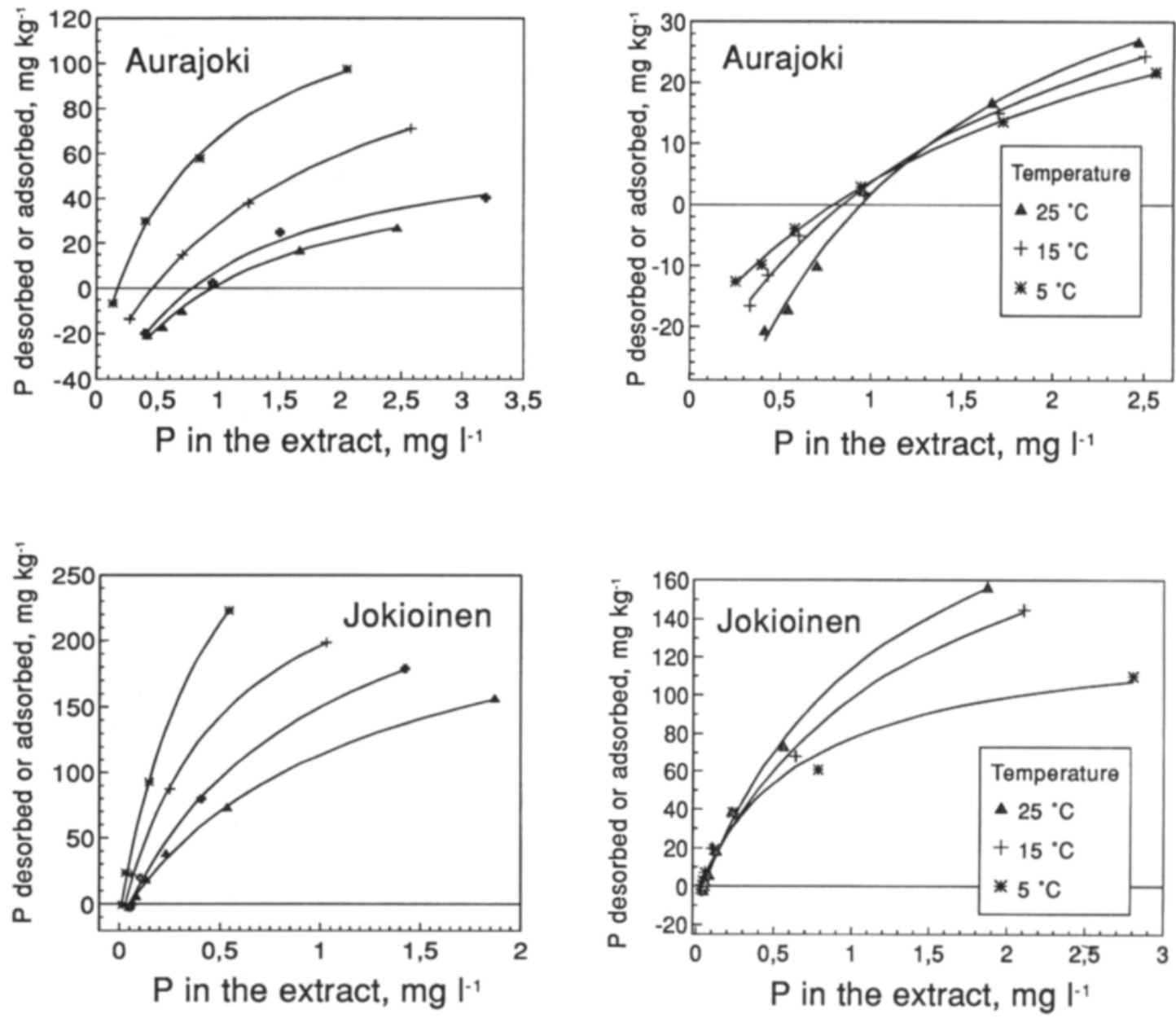

Fig. 4. Q/I plots of the Aurajoki and Jokioinen soil determined in deionized water at three temperatures at the solution-to-soil ratio of $501 \mathrm{~kg}^{-1}$. The curves displayed are calculated using the modified Langmuir equation. The constants of the equations of the curves are presented in $\mathrm{Ta}-$ ble 4 .

Fig. 3. Q/I plots of the Aurajoki and Jokioinen soil determined in deionized water and in $\mathrm{CaCl}_{2}$ solutions at the solution-to-soil ratio of $501 \mathrm{~kg}^{-1}$. The molarities in the legend refer to the concentration of $\mathrm{CaCl}_{2}$ in the extractant. The curves displayed are calculated using the modified Langmuir equation. The constants of the equations of the curves are presented in Table 4.

increase in temperature (Table 4). The plots intersected at 1.2 and $0.2 \mathrm{mg} \mathrm{Pl}^{-1}$ in the Aurajoki and Jokioinen soil, respectively, i.e. clearly

above the respective EPC values (see Table 4). In Jokioinen soil, dominated by a marked sorption tendency, the effect of temperature on the $\mathrm{P}$ exchange was small at the low $\mathrm{P}$ concentrations in the equilibrium solution. Therefore the graphs 
Vol. 5 (1996): 193-202.

Table 4. Constants of the $\mathrm{Q} / \mathrm{I}$ plots calculated from a modified Langmuir equation.

\begin{tabular}{|c|c|c|c|c|c|}
\hline & $\begin{array}{c}\text { EPC } \\
\mathrm{mg} \mathrm{l}^{-1}\end{array}$ & $\begin{array}{l}\text { EBC } \\
1 \mathrm{~kg}^{-1}\end{array}$ & $\begin{array}{c}\mathrm{Q}_{0} \\
\mathrm{mg} \mathrm{kg}^{-1}\end{array}$ & $\begin{array}{c}\mathrm{Q}_{\max } \\
\mathrm{mg} \mathrm{kg}^{-1}\end{array}$ & $\underset{1 \mathrm{mg}^{-1}}{\mathrm{~K}}$ \\
\hline \multicolumn{6}{|c|}{ Equilibration without a supporting electrolyte at 5.15 and $25^{\circ} \mathrm{C}$ : } \\
\hline \multicolumn{6}{|c|}{ Aurajoki } \\
\hline $5^{\circ} \mathrm{C}$ & 0.793 & 19.6 & 21.3 & 79 & 0.47 \\
\hline $15^{\circ} \mathrm{C}$ & 0.845 & 24.4 & 30.9 & 92 & 0.60 \\
\hline $25^{\circ} \mathrm{C}$ & 0.945 & 31.1 & 55.3 & 118 & 0.93 \\
\hline \multicolumn{6}{|l|}{ Jokioinen } \\
\hline $5^{\circ} \mathrm{C}$ & 0.024 & 186 & 4.6 & 140 & 1.42 \\
\hline $15^{\circ} \mathrm{C}$ & 0.025 & 168 & 4.4 & 248 & 0.71 \\
\hline $25^{\circ} \mathrm{C}$ & 0.050 & 212 & 11.0 & 272 & 1.18 \\
\hline \multicolumn{6}{|c|}{ Equilibration in water or $\mathrm{CaCl}_{2}$ at $25^{\circ} \mathrm{C}$ : } \\
\hline \multicolumn{6}{|c|}{ Aurajoki } \\
\hline $\mathrm{H}_{2} \mathrm{O}$ & 0.945 & 31.1 & 55.3 & 118 & 0.93 \\
\hline $0.00005 \mathrm{M}^{1}$ & 0.790 & 41.1 & 59.5 & 131 & 1.06 \\
\hline $0.0005 \mathrm{M}^{1}$ & 0.460 & 66.0 & 38.5 & 183 & 0.58 \\
\hline $0.005 \mathrm{M}^{1}$ & 0.174 & 150.3 & 31.7 & 179 & 1.24 \\
\hline \multicolumn{6}{|l|}{ Jokioinen } \\
\hline $\mathrm{H}_{2} \mathrm{O}$ & 0.050 & 212 & 11.0 & 272 & 1.18 \\
\hline $0.00005 \mathrm{M}^{1}$ & 0.051 & 309 & 16.6 & 324 & 1.06 \\
\hline $0.0005 \mathrm{M}^{1}$ & 0.028 & 567 & 16.9 & 322 & 1.96 \\
\hline $0.005 \mathrm{M}^{1}$ & 0.010 & 888 & 9.4 & 430 & 2.16 \\
\hline
\end{tabular}

${ }^{1} \mathrm{CaCl}_{2}$ concentration of the extractant.

are very close to each other and the cross-over points cannot be clearly seen in the scale used in Fig. 4.

In the Aurajoki soil, the constant $\mathrm{Q}_{0}$ increased upon elevations of temperature and in general decreased upon increasing ionic strength (Table 4). The changes of $Q_{0}$ were thus in accordance with the influence of temperature and ionic strength on desorption obtained in the desorption tests. In the Jokioinen soil, on the contrary, the response of $\mathrm{Q}_{0}$ to the changes of temperature or ionic strength was less consistent. In both soils, the values of $\mathrm{Q}_{0}$ of the $\mathrm{Q} / \mathrm{I}$ plots determined without a supporting electrolyte were less than half of the observed desorption to water at the widest solution-to-soil ratio. The values of $\mathrm{Q}_{0}$ determined in $\mathrm{CaCl}_{2}$ were $56-94 \%$ of the measured maximum desorption to the respective $\mathrm{CaCl}_{2}$ solution $(0.005 \mathrm{M}$ or $0.0005 \mathrm{M} ; 0.00005$ $\mathrm{M}$ not used in the desorption test).

\section{Discussion}

The quantity of labile adsorbed $\mathrm{P}$ on soil particles is the ultimate reserve of $\mathrm{P}$ which can be desorbed, but the DRP concentration in runoff water is also controlled substantially by ionic strength and temperature, and to some extent by the solution-to-soil ratio. The $\mathrm{P}$ buffer power of soil tends to maintain a constant DRP concentration in water, and therefore more voluminous runoff markedly increases the total quantity of DRP removed from the field.

The ionic strength of the water extracts at the solution-to-soil ratio $501 \mathrm{~kg}^{-1}$ corresponded to that of rain and snowmelt water $\left(0.3 \mathrm{mmol} \mathrm{l}^{-1}\right)$ while those of the extracts obtained at wider solution-to-soil ratios were even lower in salts. As for ionic strength, the soil extracts obtained with $0.0005 \mathrm{M} \mathrm{CaCl}_{2}$ were similar to the surface 


\section{Yli-Halla, M. \& Hartikainen, H.: Phosphorus desorption to runoff water}

runoff waters of the Jokioinen and Aurajoki fields (Yli-Halla et al. 1995), and those obtained with $0.005 \mathrm{M} \mathrm{CaCl}_{2}$ corresponded to soil solution (Wiklander and Andersson 1974). As for the solution-to-soil ratio, it was observed in an earlier study that the average DRP concentration in the surface runoff in these particular fields was the same as that of soil extracts obtained at the solution-to-soil ratio between 250 and $5001 \mathrm{~kg}^{-1}$ (Yli-Halla et al. 1995) but according to Ekholm (1994) the concentration of suspended solids in coastal river waters of Finland is lower than was applied in the present study. The equations in Fig. 1 describing the dependence of $\mathrm{P}$ desorption on ionic strength and solution-to-soil ratio thus cover the range of these factors occurring in the hydrologic environment in the field.

On the ionic strength scale used, the decrease in the salt concentration proved to effectively promote the $\mathrm{P}$ release from soil. In the water extracts, all dissolved salts originated from the soil sample, resulting in the decrease of the ionic strength of the extracts upon widening the solution-to-soil ratio. At a constant solution-tosoil ratio, decreasing ionic strength promotes $\mathrm{P}$ desorption (Hartikainen and Yli-Halla 1982). Therefore, it can be concluded that upon widening the solution-to-soil ratio the decrease of DRP concentration $\left(\mathrm{mg} \mathrm{l}^{-1}\right)$ may have been more substantial and the increase of $\mathrm{P}$ desorption $\left(\mathrm{mg} \mathrm{kg}^{-1}\right)$ less marked if the ionic strength had been kept constant. The present results thus give the net effect of two factors promoting $\mathrm{P}$ desorption: widening solution-to-soil ratio and decreasing ionic strength.

Besides DRP released in the field, surface runoff water transports $\mathrm{P}$ which is adsorbed onto the suspended soil material and which can be released as DRP in the recipient watercourse. As for the total DRP loading from the eroded material, the temperature during the runoff event may be unimportant because in the water body, the eroded material is subject also to higher temperatures during the summer months. Therefore, results obtained at a low temperature are needed to assess the DRP release in the field during the cool and wet season, while those obtained at higher temperatures are applicable to DRP release by the summer rains and to desorption taking place in a watercourse during the warmer period of the year.

Increased speed of diffusion at elevated temperatures explains the cross-over of the Q/I plots. Below the EPC, net diffusion occurs from soil to solution, resulting in a higher $\mathrm{P}$ concentration in the extract when the temperature is elevated. Above the EPC, net diffusion is from solution to soil, and an elevated temperature leads to a higher sorption. If diffusion were the only factor affected by the temperature, the curves should cross at the EPC. However, in both soils, elevation of the temperature seemed to shift the EPC to a higher concentration. At higher temperatures, a higher $\mathrm{P}$ concentration was required for sorption to start, or, vice versa, desorption continued to a higher $\mathrm{P}$ concentration. As a consequence, the crossing of the curves occurred at a P concentration above the EPC. At the EPC the net diffusion is zero. Based on the shift of the EPC, conclusions can be made on the temperature-dependency of the $\mathrm{P}$ exchange equilibrium. The shift of EPC to a higher concentration indicates that a high temperature favors desorption. This suggests sorption to be an exothermic reaction, as presented by Barrow (1979), and desorption to be an endothermic one. The parameter $\mathrm{Q}_{\max }$ stands for $\mathrm{P}$ sorption sites available. Its increase as a response to the elevated temperature can be taken to indicate that the saturation of the sorption sites is kinetically controlled.

The Q/I plots can in principle be utilized to quantify the instantly labile P of the soil (Pionke and Kunishi 1992). The physical relevance of the constant $\mathrm{Q}_{0}$ as a measure for instantly labile $\mathrm{P}$ can be assessed by comparing it with the observed desorption at wide solution-to-soil ratios, e.g. at $20001 \mathrm{~kg}^{-1}$ and with other estimates of $\mathrm{P}$ release from soil. Phosphorus bound to hydrous oxides of $\mathrm{Al}$ and $\mathrm{Fe}$ are the major reserves of bioavailable $\mathrm{P}$ in the watercourse (Dorich et al. 1985), and they control the level of water-extractable P in soil (Hartikainen 1982a). Maximum desorption in this study (solution-to-soil 
Vol. 5 (1996): 193-202.

ratio $20001 \mathrm{~kg}^{-1}, 25^{\circ} \mathrm{C}$ ) corresponded to 9 and $18 \%$ of the secondary $\mathrm{P}$ fractions $\left(\mathrm{NH}_{4} \mathrm{Cl}-\mathrm{P}+\right.$ $\mathrm{NH}_{4} \mathrm{~F}-\mathrm{P}+\mathrm{NaOH}-\mathrm{P}$, see Table 1) in the Jokioinen and Aurajoki soils, respectively, while the constant $\mathrm{Q}_{0}$ of the respective $\mathrm{Q} / \mathrm{I}$ plots amounted to only 3 and $8 \%$ of the secondary P reserves.

In an exhaustive pot experiment with one soil, Yli-Halla and Renlund (1990) measured a 30\% decrease in these $\mathrm{P}$ fractions. If this decrease is taken to represent a measure of the maximum bioavaliability of soil $\mathrm{P}$ reserves, the $\mathrm{Q}_{0}$ values markedly underestimate the potential $\mathrm{P}$ loading. Even the desorption measured at the widest solution-to-soil ratio $\left(20001 \mathrm{~kg}^{-1}\right)$ at $25^{\circ} \mathrm{C}$ may be smaller than the $\mathrm{P}$ amount that can be released from eroded soil in a watercourse. However, it should be mentioned that, particularly in the Aurajoki soil, $\mathrm{Q}_{0}$ and the $\mathrm{P}$ release in the desorption tests responded similarly to changes of ionic strength and temperature. This shows that the $\mathrm{Q} / \mathrm{I}$ plots qualitatively reflect the dynamic $\mathrm{P}$ exchange even though quantitative interpretation of the $\mathrm{Q}_{0}$ values may be questionable.

The present results show that depending on prevailing experimental conditions, a wide variation of $\mathrm{P}$ desorption results can be measured in a given soil, leading to different estimates for $\mathrm{P}$ loading. In most studies on soil samples, the $\mathrm{Q} / \mathrm{I}$ plots have been determined using a $0.01 \mathrm{M}$ supporting electrolyte (e.g. Barrow 1979). The information obtained from those $\mathrm{Q} / \mathrm{I}$ plots is applicable to $\mathrm{P}$ fertilization and the nutrition of plants. Phosphorus release to surface runoff or water bodies needs to be assessed by experiments performed at a low ionic strength and a wide (above $2001 \mathrm{~kg}^{-1}$ ) solution-to-soil ratio.

Acknowledgements. This study was financially supported by the Academy of Finland.

\section{References}

Barrow, N.J. 1979. Three effects of temperature on the reactions between inorganic phosphate and soil. Journal of Soil Science 30: 271-279.

Beckett, P.H.T. \& White, R.E. 1964. Studies on the phosphate potentials of soils. III. The pool of labile inorganic phosphate. Plant and Soil 21: 253-282.

Dorich, R.A., Nelson, D.W. \& Sommers, L.E. 1985. Estimating algal available phosphorus in suspended sediments by chemical extraction. Journal of the Environmental Quality 14: 400-405.

Ekholm, P. 1994. Bioavailability of phosphorus in agriculturally loaded rivers in southern Finland. Hydrobiologia 287: 179-194.

FAO 1988. FAO/UNESCO Soil Map of the World. Revised legend with corrections. World Resources Report 60. FAO, Rome. Reprinted as Technical paper 20 , ISRIC, Wageningen, The Netherlands. 140 p.

Griffin, R.A. \& Jurinak, J.J. 1973. Estimation of activity coefficients from the electrical conductivity of natural aquatic systems and soil extracts. Soil Science 116: 2630.

Hartikainen, H. 1979. Phosphorus and its reactions in terrestrial soils and lake sediments. Journal of the Scientific Agricultural Society of Finland 51: 537-624.

- 1982a. Water soluble phosphorus in Finnish mineral soils and its dependence on soil properties. Journal of the Scientific Agricultural Society of Finland 54: 89-98.

$-1982 b$. Relationship between phosphorus intensity and capacity parameters in Finnish mineral soils. II. Sorptiondesorption isotherms and their relation to soil characteristics. Journal of the Scientific Agricultural Society of Finland 54: 245-250.

- \& Simojoki, A. 1994. Response of soil phosphorus to acid loading. Transactions of the 15th World Congress of Soil Science 3b: 109-110.

- \& Yli-Halla, M. 1982. Chloride and sulphate solutions as extractants for soil P. I. Effect of ionic species and ionic strength on P desorption. Journal of the Scientific Agricultural Society of Finland 54: 287-296.

Holford, I.C.R. \& Mattingly, G.E.G. 1976. A model for the behavior of labile phosphate in soil. Plant and Soil 44: 219-229.

Niskanen, R. 1989. Extractable aluminium, iron and manganese in mineral soils. II. Extractability by oxalate and pyrophosphate. Journal of Agricultural Science in Finland 61: 79-87.

Pietiläinen, O.-P. \& Ekholm, P. 1992. Origin of eroded material in a small agricultural drainage basin in southwestern Finland. Aqua Fennica 22: 105-110.

Pionke, H.B. \& Kunishi, H.M. 1992. Phosphorus status and sontent of suspended sediment in a Pennsylvania watershed. Soil Science 153: 452-462.

Turtola, E. \& Jaakkola, A. 1995. Loss of phosphorus by surface runoff and leaching from a heavy clay soil under barley and grass ley in Finland. Acta Agriculturae Scandinavica Section B, Soil and Plant Sciences 45: 159-165. 


\title{
AGRICULTURAL AND FOOD SCIENCE IN FINLAND
}

Yli-Halla, M. \& Hartikainen, H.: Phosphorus desorption to runoff water

Vuorinen, J. \& Mäkitie, O. 1955. The method of soil testing in use in Finland. Agrogeological Publications 63: 144.

Wiklander, L. \& Andersson, A. 1974. The composition of the soil solution as influenced by fertilization and nutrient uptake. Geoderma 11: 157-166.

Yli-Halla, M. 1991. Phosphate adsorption characteristics of two soils responding differently to $\mathrm{P}$ fertilization.
Journal of Agricultural Science in Finland 63: 363-369. -, Hartikainen, H., Ekholm, P., Turtola, E., Puustinen, M. \& Kallio, K. 1995. Assessment of soluble phosphorus load in surface runoff by soil analyses. Agriculture, Ecosystems \& Environment 56: 53-62.

- \& Renlund, S. 1990. Solubility of residual P. Transactions of the 14th International Congress of Soil Science II: 335-336.

\section{SELOSTUS}

\section{Ympäristöolosuhteiden vaikutus maan fosforin liukenemiseen pintavalunnan aikana}

\author{
Markku Yli-Halla ja Helinä Hartikainen \\ Helsingin yliopisto
}

Pellolla kulkevaan pintavaluntaveteen liukenee fosforia (P) sekä paikalleen jäävästä maasta että veden mukana kulkevasta eroosioaineksesta. Aurajoen ja Jokioisten huuhtoutumiskentiltä otettujen savimaanäytteiden P-luovutuskykyä tutkittiin laboratoriokokein. Kokeissa pyrittiin simuloimaan pintavalunnassa vallitsevia olosuhteita uuttamalla maasta P:a eri lämpötiloissa $\left(5,15\right.$ ja $\left.25^{\circ} \mathrm{C}\right)$, eri suolakonsentraatioissa (deionisoitu vesi tai $0,00005-0,005 \mathrm{M} \mathrm{CaCl}_{2}$ ) ja käyttäen erilaisia vesi-maasuhteita $\left(50-2000 \mathrm{l} \mathrm{kg}^{-1}\right)$. Maa-aineksen kykyä sitoa ja luovuttaa P:a tutkittiin myös sorptio-desorptioisotermien avulla. Isotermit määritettiin ravistelemalla maata erivahvuisissa P-liuoksissa eri lämpötiloissa ja suolakonsentraatioissa. Kun uuttolämpötila nousi $5{ }^{\circ} \mathrm{C}$ :sta $25^{\circ} \mathrm{C}$ :een, vesi-maasuhteella $501 \mathrm{~kg}^{-1}$ Aurajoen maasta veteen uuttuneen P:n määrä kasvoi arvosta $12,6 \mathrm{mg} \mathrm{kg}^{-1}$ ar- voon $20,7 \mathrm{mg} \mathrm{kg}^{-1}$ ja Jokioisten maassa arvosta 1,8 $\mathrm{mg} \mathrm{kg}^{-1}$ arvoon $3,4 \mathrm{mg} \mathrm{kg}^{-1}$. Kun maata uutettiin deionisoidun veden asemesta maaveden suolapitoisuutta jäljittelevällä $0,005 \mathrm{M} \mathrm{CaCl}_{2}: 1 l a$, uuttuneet $\mathrm{P}$-määrät Aurajoen maasta pienenivät $6,8 \mathrm{mg} \mathrm{kg}^{-1}: \mathrm{aan}$ ja Jokioisten maasta $0,7 \mathrm{mg} \mathrm{kg}^{-1}$ :aan. Vesi-maasuhteen väljentäminen $2000 \mathrm{I} \mathrm{kg}^{-1}$ :aan puolestaan lisäsi P:n uuttumista veteen Aurajoen maassa kuusinkertaiseksi (119 $\mathrm{mg} \mathrm{kg}^{-1}$ :aan) ja Jokioisten maassa 14-kertaiseksi (46 mg kg-1:aan). Lämpötilan ja suolapitoisuuden kohotessa pidättyi maahan lisätystä P:sta yhä suurempi osuus. Saatujen tulosten perusteella voidaan päätellä, että pellolta tulevan pintavalunnan liukoisen P:n pitoisuuteen ja vesistökuormituksen suuruuteen vaikuttavat oleellisesti maan helppoliukoisen P:n pitoisuuden ohella myös valumaveden määrä, sen lämpötila ja suolapitoisuus. 